\title{
Synthesis and Characterization of Hybrid Polymer Based on Functionalized Silica as Efficient Adsorbent for Heavy Metal Ions from Aqueous Solution
}

\author{
Ariane C. Ribicki, ${ }^{a}$ Mayara L. Sperandio, ${ }^{a}$ Viviane J. Van Haandel, ${ }^{a}$ Ruben A. Estrada ${ }^{b}$ \\ and Sérgio T. Fujiwara ${ }^{\circledR} * a$ \\ ${ }^{a}$ Departamento de Química, Universidade Estadual de Ponta Grossa, \\ 84030-900 Ponta Grossa-PR, Brazil \\ ${ }^{b}$ Departamento de Física, Universidade Estadual de Ponta Grossa, \\ 84030-900 Ponta Grossa-PR, Brazil
}

\begin{abstract}
An organic-inorganic hybrid material based on a silica matrix and functionalized with imidazole group was successfully synthesized by the sol-gel process. The characterization techniques enabled the confirmation of the proposed structure as well as the effectiveness of the imidazole ring functionality in the structure of the material. It is insoluble in water and showed an anion exchange capacity of $2.944 \mathrm{mmol} \mathrm{g}^{-1}$, an excellent capacity for the adsorption of metal ions according to the literature. Thus, the metal halides $\mathrm{CuCl}_{2}, \mathrm{CdCl}_{2}$ and $\mathrm{NiCl}_{2}$ were adsorbed by the modified silsesquioxane from aqueous solutions. The adsorption isotherms results showed the availability of 3- $n$-propylimidazolium silsesquioxane chloride $\left(\mathrm{SiImi}^{+} \mathrm{Cl}^{-}\right)$as an efficient adsorbent material in the adsorption of metal ions, exhibiting a higher affinity for the $\mathrm{Cu}^{2+}$ ions at $\mathrm{pH} 4$, with a maximum adsorption capacity of $2.80 \mathrm{mmol} \mathrm{g}^{-1}$. The Langmuir, Freundlich and Sips models were applied to the adsorption isotherms, both the $\mathrm{pH}$ and the nature of the ion were observed to be factors that influence the adjustment of the isotherms to the proposed models.
\end{abstract}

Keywords: sol-gel process, imidazole, adsorption isotherms, silsesquioxane, adsorption of metal ions

\section{Introduction}

The release of toxic heavy metals in the environment has been a cause of concern due to their non-degradability, bioaccumulation and consequent toxicity for the life of humans and other living beings. Various emissions such as industrial waste, agriculture and ecological disasters are responsible for the presence of these compounds in the atmosphere and ground water, for example..$^{1-3}$ These compounds when bioaccumulated in our body by ingestion of contaminated food, water and air induce the production of free radicals and reactive nitrogen species which cause deoxyribonucleic acid (DNA) damage, several damages to the living tissues and can initiate a series of diseases, such as cancer. ${ }^{4-7}$ Therefore, it is extremely important to develop more sensitive and reliable methods for detecting, monitoring and treating heavy metals in environmental and biological samples.

Among the various heavy metal removal methods available, such as chemical precipitation, ${ }^{8,9}$ ion exchange, ${ }^{10-12}$

*e-mail: sergiofujiwara@gmail.com adsorption, ${ }^{13-17}$ and membrane filtration, ${ }^{18-20}$ the adsorption appears to be an effective and economic method due to its simplicity and low cost. For this purpose, there are reports of many adsorbents, ${ }^{21-25}$ but the silica-based compounds as silsesquioxanes have generated considerable interest due to their mechanical and thermal stability, well-established particle sizes, well-defined porosity and high surface area. ${ }^{26-31}$ Besides presenting high chemical reactivity due to the presence of silanol groups ( $\mathrm{Si}-\mathrm{OH})$, these compounds when modified with functional groups, mainly nitrogencontaining ligands, improve the selectivity and adsorption capacity of adsorbents. ${ }^{32-34}$ Tzvetkova et al. ${ }^{33}$ reported that a silica-based compound modified with 5-amino1,3,4-thiadiazole-2-thiol was characterized by a higher sorption capacity of metals than the unmodified one. For example, the sorption capacity of $\mathrm{Hg}^{2+}$ by the modified silica-based compound was $8.44 \mathrm{mg} \mathrm{g}^{-1}$, while by the unmodified silica it was $2.67 \mathrm{mg} \mathrm{g}^{-1}$.

Silsesquioxanes are organic-inorganic hybrid materials that have organofunctional groups attached to silica matrices. ${ }^{35}$ The pendant organic groups can be linked to the inorganic core mainly in two ways, by sol-gel 
pathways to obtain a hybrid network through hydrolysis and condensation of organically modified metal alkoxides or metal halides and the grafting. ${ }^{36,37}$ The grafting refers to post-synthesis modification of a pre-fabricated silica core by the attachment of functional molecules to the surface of the silica matrix. ${ }^{38,39}$ Fujiwara et al. ${ }^{40}$ reported a charged silsesquioxane prepared by attaching pyridine group grafted onto the silica gel surface. The silsesquioxane demonstrated large exchange capacity associated with high affinity for $\mathrm{Fe}^{3+}, \mathrm{Cu}^{2+}$ and $\mathrm{Zn}^{2+}$. Furthermore, the film was used in various cycles of metal ions adsorption-elution operations without detectable loss of exchange capacity. Magosso et al..$^{41}$ proved that the fixation of $\mathrm{Zn}^{2+}, \mathrm{Cd}^{2+}$ and $\mathrm{Hg}^{2+}$ by affinity constants occurs in the form of anionic metal complexes on the silica surface with methylpyridine group. The compound presented high exchange capacity, good chemical and thermal stability.

Thus, in this study, the 3-n-propylimidazolium silsesquioxane chloride polymer designated $\mathrm{SiImi}^{+} \mathrm{Cl}^{-}$ prepared by sol gel process was used as adsorbent material. This organic-inorganic hybrid material was applied in the adsorption processes of heavy metals, such $\mathrm{Cu}^{2+}, \mathrm{Ni}^{2+}$ and $\mathrm{Cd}^{2+}$ from aqueous solution and were quantitatively evaluated using the Langmuir, Freundlich and Sips models. The material was chemically prepared with imidazole, an organofunctional group extensively reported in the literature due to the fact that nitrogen atoms present in this molecule allow its coordination with a variety of transition metal ions. ${ }^{42,43}$

\section{Experimental}

\section{Synthesis of 3-n-propylimidazolium silsesquioxane chloride $\left(\mathrm{Silmi}{ }^{+} \mathrm{Cl}^{-}\right.$)}

The 3-chloropropyltrimethoxysilane, tetraethylorthosilicate, ethanol and imidazole were of analytical grade purity, from Sigma Aldrich (São Paulo, Brazil) and used as received. In a round bottom flask, $40 \mathrm{mmol}$ imidazole was dissolved in $20 \mathrm{~mL}$ ethanol and $40 \mathrm{mmol}$ 3 -chloropropyltrimethoxysilane were added. The mixture was stirred under argon atmosphere at around $350 \mathrm{~K}$ for $1 \mathrm{~h}$. After that, tetraethylorthosilicate $(5.95 \mathrm{~mL})$ dissolved in ethanol, was added in the flask and stirred until the formation of a solid. The Figure 1 showed the reaction product, $\mathrm{SiImi}^{+} \mathrm{Cl}^{-}$(Figure 1a) that was rotaevaporated to eliminate the solvent. The solid obtained was macerated and passed through 60 to 250 mesh sieves. The same procedure was done to obtain the silica-based material unmodified with imidazole, 3- $n$-propyl silsesquioxane chloride or $\mathrm{SiCl}$ (Figure 1b).

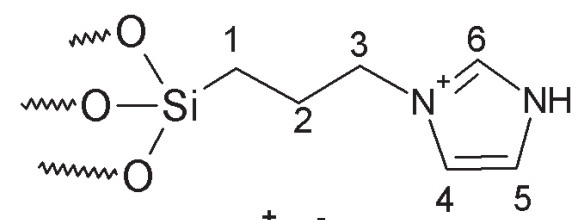

(a) Silmi ${ }^{+} \mathrm{Cl}^{-}$

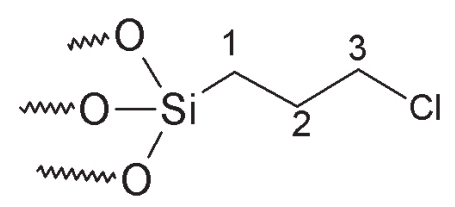

\section{(b) $\mathrm{SiCl}$}

Figure 1. Arrangements of the carbon chain in the silsesquioxane structure (a) $\mathrm{SiImi}^{+} \mathrm{Cl}^{-}$; (b) $\mathrm{SiCl}$.

\section{Solid state nuclear magnetic resonance}

Solid state ${ }^{13} \mathrm{C}$ and ${ }^{29} \mathrm{Si}$ nuclear magnetic resonance (NMR) experiments were performed on a Bruker Advance III 400 spectrometer. For solid state experiments, the variable amplitude cross-polarization magic angle spinning (VACP-MAS) pulse sequence was implemented using a standard MAS probe $4 \mathrm{~mm}$ at room temperature. For ${ }^{13} \mathrm{C}$ and ${ }^{29} \mathrm{Si}$ signals, glycine and kaolin samples (Sigma Aldrich, São Paulo, Brazil) were established as patterns, respectively. The samples were placed on a Kel-F rotor and they were spun at $12 \mathrm{kHz}\left({ }^{13} \mathrm{C}\right)$ and $8 \mathrm{kHz}\left({ }^{29} \mathrm{Si}\right)$. The cross-polarization pulse sequence was accomplished at $1 \mathrm{~ms}$ contact time value and $17.9 \mathrm{~ms}$ acquisition time to ${ }^{13} \mathrm{C}$, while the ${ }^{29} \mathrm{Si}$ measurements was $9.5 \mathrm{~ms}$ contact time value and $24.9 \mathrm{~ms}$ acquisition time, during this time a SPINAL-64 pulse sequence was performed for the decoupling process between hydrogen nuclei and carbon/ silicon nuclei. ${ }^{44}$ The recycle time delay was $0.5 \mathrm{~s}$ to ${ }^{13} \mathrm{C}$ and $5.0 \mathrm{~s}$ to ${ }^{29} \mathrm{Si}$.

\section{Infrared analysis}

Fourier transform infrared spectroscopy (FTIR) measurements were carried out in an infrared spectrometer FTIR SHIMADZU (Prestige 21) on a transmission mode. Spectra were collected in the range 400 to $4000 \mathrm{~cm}^{-1}$ at $2 \mathrm{~cm}^{-1}$ resolutions with 64 scans, using a pressed $\mathrm{KBr}$ (Sigma Aldrich, São Paulo, Brazil) disk with each sample.

\section{X-ray diffraction}

The X-ray diffraction (XRD) patterns of the powdered samples were obtained in a Rigaku diffractometer model Ultima IV using $\mathrm{Cu} \mathrm{K} \alpha(\lambda=0.15418)$ as radiation source. 
Ion exchange capacity

The ion exchange capacity of the polymer $\mathrm{SiImi}^{+} \mathrm{Cl}^{-}$ was determined by immersing $0.1 \mathrm{~g}$ of the material into $30 \mathrm{~mL} 0.1 \mathrm{~mol} \mathrm{~L}^{-1} \mathrm{HNO}_{3}$ (65\%, Biotec, São Paulo, Brazil) aqueous solution and the amount of chloride ion released was determined by potentiometric titration, under stirring with standard $0.01 \mathrm{~mol} \mathrm{~L}^{-1} \mathrm{AgNO}_{3}$ (99\%, Vetec, São Paulo, Brazil) solution. The exchange capacity, $\mathrm{N}_{0}$, obtained was $2.944 \pm 0.004 \mathrm{mmol} \mathrm{g}^{-1}$.

\section{Adsorption isotherms}

The adsorption isotherms of the metal ions were obtained at $301.15 \mathrm{~K}$ in aqueous solutions by the batch technique. About $0.01 \mathrm{~g}$ of the adsorbent was immersed in $10 \mathrm{~mL}$ metal halides solution, $\mathrm{CuCl}_{2}, \mathrm{NiCl}_{2}$ and $\mathrm{CdCl}_{2}$, (all 97-99\%) from Synth (São Paulo, Brazil) of variable concentrations, from 0.0735 to $8.82 \mathrm{mmol} \mathrm{L}^{-1}$ and the mixture was shaken for $8 \mathrm{~h}$. The amount of metal ions adsorbed by the solid phase, $\mathrm{N}_{\mathrm{f}}$, was calculated by applying the equation $N_{f}=\left(N_{a}-N_{s}\right) / m$, where $\mathrm{N}_{\mathrm{a}}$ is the initial metal mol number and $\mathrm{N}_{\mathrm{s}}$ the metal mol number in equilibrium with the solid phase, and $\mathrm{m}$ is the mass weight of the adsorbent. The metals in the solution phase were determined by atomic absorption spectroscopy (FAAS) VARIAN, model AA240FS.

\section{Results and Discussion}

Figures 2 and 3 present the solid state ${ }^{13} \mathrm{C}$ and ${ }^{29} \mathrm{Si}$ VACP-MAS NMR spectra for SiImi ${ }^{+} \mathrm{Cl}^{-}$and the unmodified sample, $\mathrm{SiCl}$. These spectra were acquired to have structural information about the functional molecules bound to the surfaces.

The ${ }^{13} \mathrm{C}$ NMR spectra (Figures 2a and 2b) showed specific peak positions assigned according to the numbers shown in Figure 1. The results present signals at 10, 26 and $47 \mathrm{ppm}$ to $\mathrm{SiCl}$ (Figure $2 \mathrm{a}$ ) assigned to $\mathrm{C}_{1}, \mathrm{C}_{2}$, and $\mathrm{C}_{3}$, respectively. The peaks at 10, 24 and $50 \mathrm{ppm}$ to $\mathrm{SiImi}^{+} \mathrm{Cl}^{-}$ assigned to $\mathrm{C}_{1}, \mathrm{C}_{2}$, and $\mathrm{C}_{3}$, respectively. On the other hand, $\mathrm{SiImi}^{+} \mathrm{Cl}^{-}$showed peaks at 122 and $136 \mathrm{ppm}$ which are attributed to $\mathrm{C}_{4,5}$ and $\mathrm{C}_{6}$ of the imidazole ring, respectively (Figure $2 \mathrm{~b}$ ). The greater chemical shifts of $\mathrm{C}_{4,5}$ and $\mathrm{C}_{6}$ for $\mathrm{SiImi}^{+} \mathrm{Cl}^{-}$indicate the presence of carbons bound to a high charge density group, like nitrogen. The small intense peaks at 18 and 58 ppm, observable in Figure 2a, are due to the unreacted n-propyl groups. ${ }^{45-48}$

Figure 3 presents the ${ }^{29} \mathrm{Si} \mathrm{NMR}$ spectra for $\mathrm{SiCl}$ and $\mathrm{SiImi}^{+} \mathrm{Cl}^{-}$. The signals around $-110 \mathrm{ppm}$ are attributed to $\mathrm{Si}(\mathrm{OSi})_{4}$ or $\mathrm{Q}^{4}$ species. The peaks at $-102 \mathrm{ppm}$ correspond to $\mathrm{Si}(\mathrm{OSi})_{3} \mathrm{OH}$ or $\mathrm{Q}^{3}$ species. The $\mathrm{Q}$ units are attributed to $\mathrm{Si}$

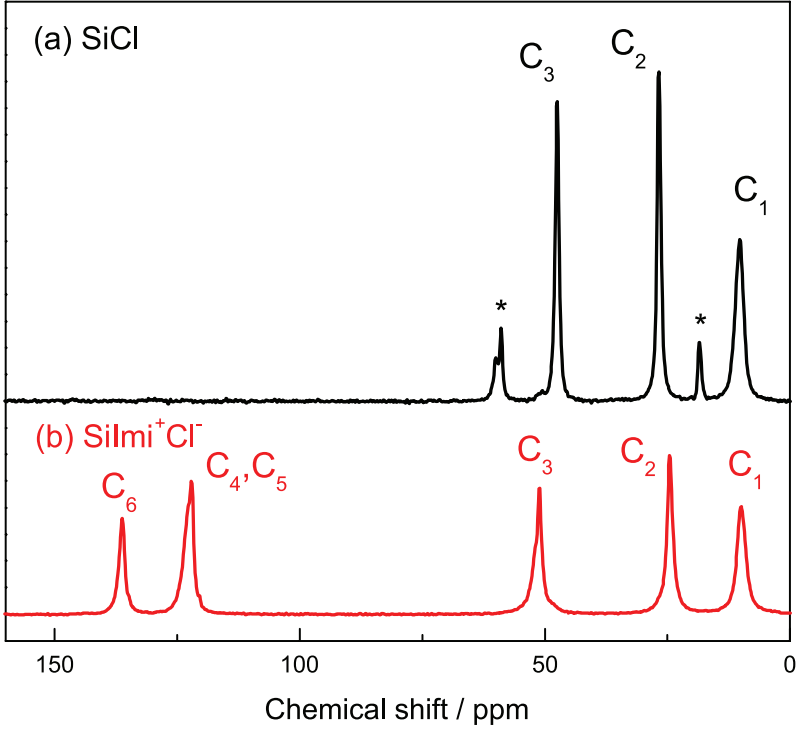

Figure 2. Solid state NMR spectra by performing the VACP-MAS pulse sequences to detect ${ }^{13} \mathrm{C}$ nuclei (a) $\mathrm{SiCl}$; (b) $\mathrm{SiImi}^{+} \mathrm{Cl}^{-}$.

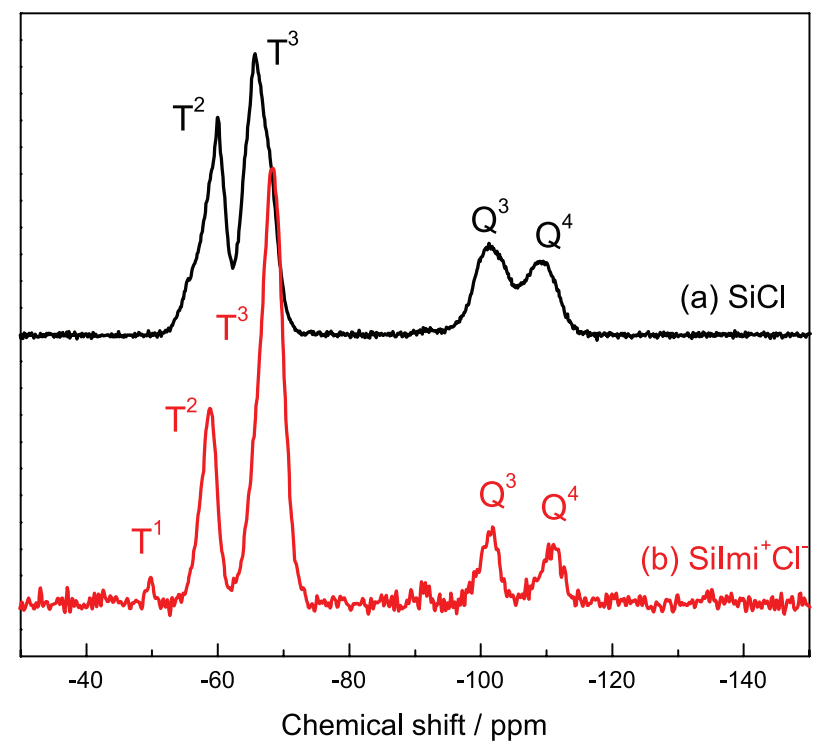

Figure 3. Solid state NMR spectra by performing the VACP-MAS pulse sequences to detect ${ }^{29} \mathrm{Si}$ nuclei (a) $\mathrm{SiCl}$; (b) $\mathrm{SiImi}^{+} \mathrm{Cl}^{-}$.

atoms of the inorganic silica matrix in the siloxane binding environment without hydroxyl groups $\left(\mathrm{Q}^{4}\right)$ or present an isolated silanol group $\left(\mathrm{Q}^{3}\right)$. In addition, the signals around -67 ppm may be assigned to the silicon atom of the RSi(OSi) or $\mathrm{T}^{3}$ structures. ${ }^{45-47}$ The peaks around $-58 \mathrm{ppm}$ are assigned to $\mathrm{RSi}(\mathrm{OSi})_{2} \mathrm{OH}$ and correspond to the $\mathrm{T}^{2}$ signals. The other peak at $-50 \mathrm{ppm}$ is attributed to $\mathrm{RSi}(\mathrm{OSi})(\mathrm{OH})_{2}$ or $\mathrm{T}^{1}$ units. The presence of $\mathrm{T}^{3}, \mathrm{~T}^{2}$ and $\mathrm{T}^{1}$ signals confirms that the organic groups are covalently bound to the silica surface. ${ }^{49,50}$

FTIR spectra of $\mathrm{SiCl}$ (Figure $4 \mathrm{a}$ ) and $\mathrm{SiImi}^{+} \mathrm{Cl}^{-}$ (Figure 4b) displayed bands characteristic for silsesquioxane backbone, with the bands at $1100 \mathrm{~cm}^{-1}$ and $790 \mathrm{~cm}^{-1}$ ascribed to the asymmetric and symmetric vibrations of the 
siloxane groups ( $\mathrm{Si}-\mathrm{O}-\mathrm{Si})$, respectively. The bands around 3500 and $1630 \mathrm{~cm}^{-1}$ were due to the bonding deformation of silanol group $\mathrm{Si}-\mathrm{OH}$ and adsorbed water. Around $470 \mathrm{~cm}^{-1}$ they were assigned to the bonding deformation $\mathrm{Si}-\mathrm{O}-\mathrm{Si}$. The peaks at $2900 \mathrm{~cm}^{-1}$ were attributed to the $\mathrm{C}-\mathrm{H}$ stretching vibration of propyl groups. In addition, all the vibrations mentioned appeared in both materials and were formed during the hydrolysis-condensation reaction of 3-chloropropyltrimetoxysilane and tetraethylorthosilicate. ${ }^{51}$ In the spectrum of $\mathrm{SiImi}^{+} \mathrm{Cl}^{-}$, a band was assigned between the regions $1411-1632 \mathrm{~cm}^{-1}$, due to the ring stretching vibration of the imidazole ligand, corresponding to $\mathrm{C}=\mathrm{N}, \mathrm{C}-\mathrm{N}$ and $\mathrm{C}=\mathrm{C}$ stretching of the heterocyclic ring. Furthermore, a peak appeared at $3000 \mathrm{~cm}^{-1}$ which refers to the $\mathrm{C}-\mathrm{H}$ stretching vibration of imidazole ring. ${ }^{51-53}$

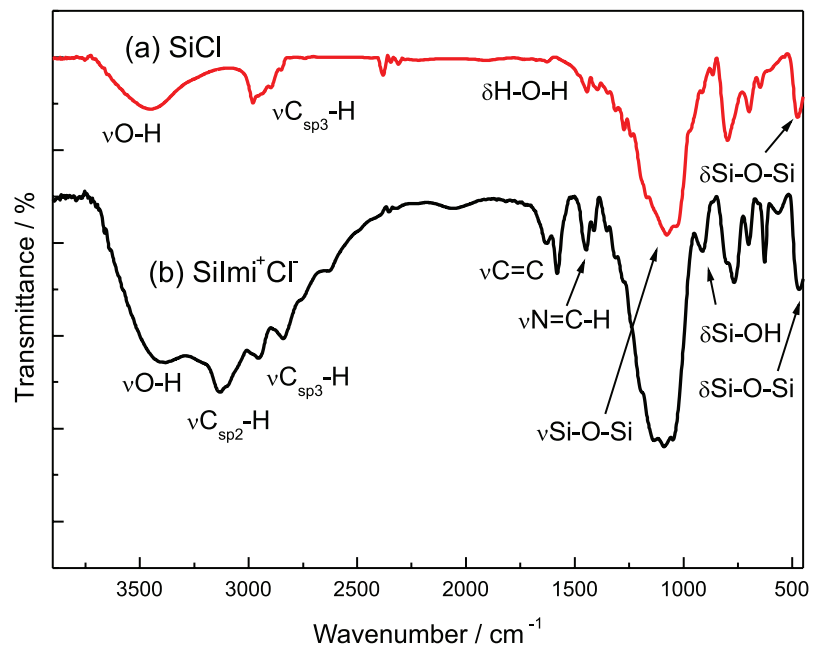

Figure 4. FTIR spectra of (a) $\mathrm{SiCl}$ and (b) $\mathrm{SiImi}^{+} \mathrm{Cl}^{-}$made in $\mathrm{KBr}$ pellets.

As shown in Figure 5, the XRD patterns of the $\mathrm{SiCl}$ (Figure 5a) and $\mathrm{SiImi}^{+} \mathrm{Cl}^{-}$(Figure 5b) samples exhibited two characteristic peaks. Based on the literature, ${ }^{54-58}$ the products are amorphous but the sharp diffraction peak $\mathrm{d}_{1}$ that was assigned to the intramolecular periodic chain-tochain distance, indicates layered silsesquioxane compounds or lamellar silica. The peak $\mathrm{d}_{2}$ is quite broad in all products and although its maximum is rather difficult to determine, it can be ascribed due to the halo of amorphous silica and the contribution of the Si-O-Si units. ${ }^{59,60}$ However, an increase in the $\mathrm{d}_{1}$-spacing, of approximately $3 \AA$ was allowed due to the imidazole incorporation in the silica matrix structure. These results indicated that the final material synthesis was successful.

\section{Adsorption isotherms}

There are many reports in the literature ${ }^{61-63}$ describing materials containing imidazole as adsorbents of metal ions,

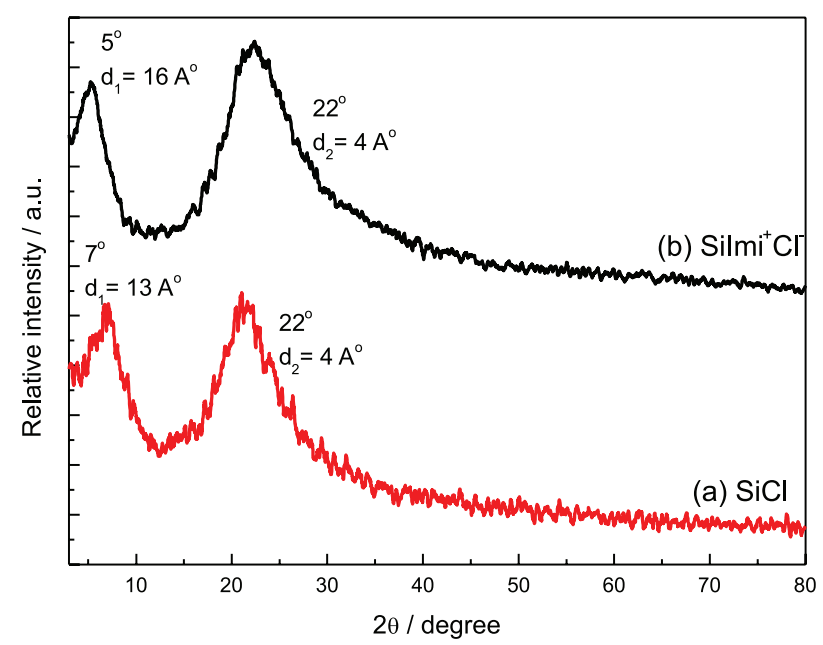

Figure 5. Powder XRD patterns of (a) $\mathrm{SiCl}$ and (b) $\mathrm{SiImi}^{+} \mathrm{Cl}^{-}$.

the adsorption capacity of metal ions is due to the presence of a coordinating nitrogen in imidazole. Due to this fact the synthesis of a silsesquioxane containing imidazole in its structure becomes very interesting. Several silsesquioxanes have been synthesized and applied in the adsorption of metal ions. ${ }^{40,41,64} \mathrm{SiPy}^{+} \mathrm{Cl}^{-}$(3- $n$-propylpyridinium silsesquioxane chloride), is one of them, which has already been used in adsorption of metal halides from ethanol solutions. ${ }^{64}$ The parameters as the time to reach equilibrium and the ratio between the mass of the adsorbent and metallic ions concentration were based on preliminary tests.

The influence of the $\mathrm{pH}$ value is an important factor in adsorptive processes, due to this fact, the adsorption studies of the metal ions were carried out at different $\mathrm{pH}$ values as shown in Figure 6. This figure shows that the adsorption of metal ions decreases with the acidity of the solution. Obviously, a pH range of 4.0-6.0 is optimal for the adsorption of metal ions. Adsorption experiments at $\mathrm{pH}$ values higher than 6.0 were not carried out because of the risk of precipitation into hydroxide species. ${ }^{15,16,65,66}$ At $\mathrm{pH} 2.0$ the least adsorption of metallic ions was found, like other works. ${ }^{66,67}$ This result may be because the high concentration of protons strongly competes with metallic ions to interact with the nitrogen groups, decreasing ions adsorption. ${ }^{66,67}$ Through species diagrams (Supplementary Information section), $\mathrm{Cu}^{2+}, \mathrm{Ni}^{2+}$ and $\mathrm{Cd}^{2+}$ in aqueous media at $\mathrm{pH}$ above 3.0 were also seen to exist in the forms of $\mathrm{Cu}(\mathrm{OH})^{+}, \mathrm{Cu}_{2}(\mathrm{OH})_{2}{ }^{2+}, \mathrm{Cu}_{2} \mathrm{OH}^{3+}, \mathrm{NiOH}^{+}$and $\mathrm{CdOH}^{+}$, which favor adsorption processes. This leads to the assumption that nitrogen groups adsorb hydroxyl ions from the solution through hydrogen bonds, increasing the adsorption values. ${ }^{66}$ However, at $\mathrm{pH}$ around 4.5 for $\mathrm{Cu}^{2+}$ the precipitation of $\mathrm{CuCl}_{2}: 3 \mathrm{Cu}(\mathrm{OH})_{2}$ and $\mathrm{CuO}$ gradually occur on the surface of the adsorbent, decreasing significantly the adsorption of copper ions. 

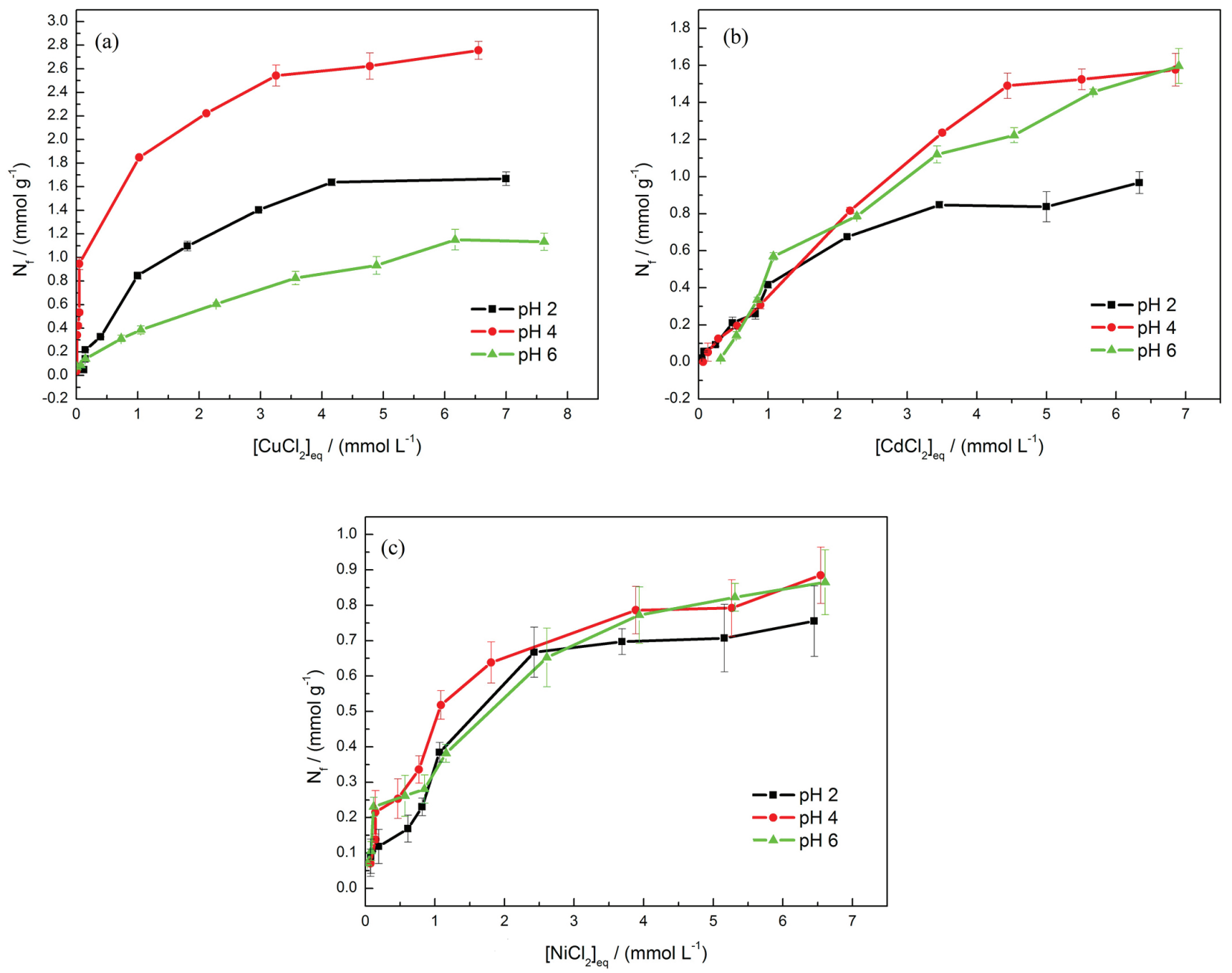

Figure 6. Adsorption isotherm of (a) $\mathrm{Cu}^{2+}$ ions, (b) $\mathrm{Cd}^{2+}$ ions and (c) $\mathrm{Ni}^{2+}$ ions on $\mathrm{SiImi}^{+} \mathrm{Cl}^{-}$.

The Langmuir, Freundlich and Sips isotherm models were used to interpret and evaluate the adsorption data from the experiments performed at $\mathrm{pH}$ from 2.0-6.0. The Langmuir model (equation 1) assumes the monolayer and uniform adsorption of adsorbate onto a homogenous adsorbent surface. ${ }^{68}$ The Freundlich isotherm (equation 2) assumes a non-ideal and reversible adsorption on multilayer heterogeneous surface with interaction between the adsorbate molecules. ${ }^{68}$ In equations 1,2 and $3 \mathrm{~N}_{\mathrm{f}}\left(\mathrm{mmol} \mathrm{g}^{-1}\right)$ is the adsorption capacity at equilibrium, $\mathrm{N}_{\mathrm{c}}\left(\mathrm{mmol} \mathrm{L}^{-1}\right)$ is the equilibrium concentration of the metal ions, $\mathrm{N}_{\mathrm{f}}^{\text {max }}\left(\mathrm{mmol} \mathrm{g}^{-1}\right)$ is the Langmuir monolayer adsorption capacity, $\mathrm{K}_{\mathrm{L}}$ $\left(\mathrm{L} \mathrm{mmol}^{-1}\right)$ is the Langmuir constant, $\mathrm{K}_{\mathrm{F}}\left(\mathrm{mmol} \mathrm{g}^{-1}\right)$ is the Freundlich parameter, and $1 / \mathrm{n}$ is the adsorption intensity. ${ }^{66}$

$\frac{\mathrm{N}_{\mathrm{c}}}{\mathrm{N}_{\mathrm{f}}}=\frac{1}{\mathrm{~N}_{\mathrm{f}}^{\text {máx }}} \times \mathrm{K}_{\mathrm{L}}+\frac{\mathrm{N}_{\mathrm{c}}}{\mathrm{N}_{\mathrm{f}}^{\text {máx }}}$

$\ln \left(\mathrm{N}_{\mathrm{f}}\right)=\ln \left(\mathrm{K}_{\mathrm{F}}\right)+\frac{1}{\mathrm{n}} \times \ln \left(\mathrm{N}_{\mathrm{c}}\right)$
The Sips isotherm is a combination of Langmuir and Freundlich isotherms, which incorporate three parameters into an empirical equation. At low adsorbate concentration this model reduces to the Freundlich model, but at high concentration of adsorbate, it predicts the Langmuir model (monolayer adsorption). ${ }^{68}$ In equation $3, \mathrm{Q}_{\text {sat }}\left(\mathrm{mmol} \mathrm{g}^{-1}\right)$ is the Sips adsorption capacity, $\mathrm{K}\left(\mathrm{L} \mathrm{mmol}^{-1}\right)$ is Sips isotherm exponent, and $\mathrm{n}$ is Sips isotherm model constant. The constant $\mathrm{n}$ describes the surface heterogeneity and when equals unity, the Sips isotherm returns to the Langmuir isotherm and predicts homogeneous adsorption. On the other hand, deviation of $\mathrm{n}$ value from the unity indicates heterogeneous surface. ${ }^{69}$ The parameters $\mathrm{Q}_{\text {sat }}, \mathrm{K}$ and $\mathrm{n}$ are determined from nonlinear regression analysis.

$\mathrm{N}_{\mathrm{f}}=\frac{\mathrm{Q}_{\text {sat }} \times\left(\mathrm{K} \times \mathrm{N}_{\mathrm{c}}\right)^{\mathrm{n}}}{1+\left(\mathrm{K} \times \mathrm{N}_{\mathrm{c}}\right)^{\mathrm{n}}}$

The values of isotherms parameters obtained are shown in Table 1. 
Table 1. Langmuir, Freundlich and Sips parameters for metal adsorption on $\mathrm{SiImi}^{+} \mathrm{Cl}^{-}, \mathrm{pH}$ 2.0-6.0

\begin{tabular}{|c|c|c|c|c|c|c|c|c|c|c|c|}
\hline \multirow[b]{2}{*}{ Metal ion } & \multirow[b]{2}{*}{$\mathrm{pH}$} & \multicolumn{3}{|c|}{ Langmuir } & \multicolumn{4}{|c|}{ Freundlich } & \multicolumn{3}{|c|}{ Sips } \\
\hline & & $\begin{array}{c}\mathrm{N}_{\mathrm{f}}^{\text {máx } /} \\
\left(\mathrm{mmol} \mathrm{g}^{-1}\right)\end{array}$ & $\begin{array}{c}\mathrm{K}_{\mathrm{L}} / \\
\left(\mathrm{L} \mathrm{mmol}^{-1}\right)\end{array}$ & $r^{2}$ & $\begin{array}{c}\mathrm{K}_{\mathrm{F}} / \\
\left(\mathrm{mmol} \mathrm{g}^{-1}\right)\end{array}$ & $\mathrm{n}$ & $r^{2}$ & $\begin{array}{c}\mathrm{Q}_{\text {sat }} / \\
\left(\mathrm{mmol} \mathrm{g}^{-1}\right)\end{array}$ & $\begin{array}{c}\mathrm{K} / \\
\left(\mathrm{L} \mathrm{mmol}^{-1}\right)\end{array}$ & $\mathrm{n}$ & $r^{2}$ \\
\hline \multirow{3}{*}{$\mathrm{Cu}^{2+}$} & 2 & 2.55 & 0.34 & 0.849 & 0.57 & 1.31 & 0.942 & 1.93 & 0.71 & 1.21 & 0.989 \\
\hline & 4 & 2.80 & 3.47 & 0.996 & 1.55 & 2.07 & 0.906 & 3.56 & 1.15 & 0.82 & 0.997 \\
\hline & 6 & 1.31 & 0.61 & 0.957 & 0.42 & 2.22 & 0.971 & 2.37 & 1.05 & 0.63 & 0.988 \\
\hline \multirow{3}{*}{$\mathrm{Cd}^{2+}$} & 2 & 1.38 & 0.36 & 0.967 & 0.30 & 1.31 & 0.983 & 1.07 & 0.57 & 1.35 & 0.986 \\
\hline & 4 & 4.53 & 0.09 & 0.870 & 0.35 & 1.11 & 0.994 & 1.97 & 0.23 & 1.56 & 0.993 \\
\hline & 6 & 2.83 & 0.18 & 0.961 & 0.35 & 1.18 & 0.980 & 2.30 & 0.20 & 1.20 & 0.978 \\
\hline \multirow{3}{*}{$\mathrm{Ni}^{2+}$} & 2 & 0.93 & 0.66 & 0.960 & 0.30 & 1.83 & 0.978 & 0.79 & 0.76 & 1.72 & 0.976 \\
\hline & 4 & 1.02 & 0.76 & 0.974 & 0.36 & 1.99 & 0.965 & 1.16 & 0.65 & 0.81 & 0.981 \\
\hline & 6 & 1.07 & 0.74 & 0.971 & 0.38 & 2.20 & 0.978 & 1.83 & 0.59 & 0.50 & 0.983 \\
\hline
\end{tabular}

$\mathrm{N}_{\mathrm{f}}^{\text {máx: }}$ Langmuir adsorption capacity; $\mathrm{K}_{\mathrm{L}}$ : Langmuir constant; $\mathrm{K}_{\mathrm{F}}$ : Freundlich parameter; n: adsorption intensity, $\mathrm{Q}_{\text {sat }}$ : Sips adsorption capacity; K: Sips constant; $\mathrm{n}$ : surface heterogeneity; $\mathrm{r}^{2}$ : regression coefficients.

The adsorptions models were observed analyzing the regression coefficients for metal ions. In $\mathrm{Cu}^{2+}$ case, both the Langmuir and Sips isotherm models fitted better than Freundlich model at $\mathrm{pH}$, indicating that the Sips isotherm equation reduced to the Langmuir equation and a monolayer adsorption with heterogeneous distribution of the active sites occurred on adsorbent surface. At $\mathrm{pH} 2$ and 6 , occurred a heterogeneous adsorption because the interference of the species like $\mathrm{H}^{+}$and the precipitation of the copper compound, thus the Sips model was seen as the most appropriate. The Sips and Freundlich isotherm models well fit the experimental data to $\mathrm{Cd}^{2+}$, which indicated that homogenous and heterogeneous adsorption occurred on the surface of adsorbent. In the case of the regression coefficients for the $\mathrm{Ni}^{2+}$, the heterogeneity of the system was also observed and the model that best fitted the experimental data was the Sips model. In general, the founded Sips $\mathrm{r}^{2}$ indicates the absorption of $\mathrm{SiImi}^{+} \mathrm{Cl}^{-}$was not only simple single molecule adsorption but also complex mixed adsorption. ${ }^{69,70}$

According to the results, loading capacities were found to decrease in the following order $\mathrm{Cu}^{2+}>\mathrm{Cd}^{2+}>\mathrm{Ni}^{2+}$ and they agreed with previous studies. ${ }^{14,15,25,33,71}$ So, this selectivity is mainly based on hydrated metal cations. The higher $\mathrm{Cu}^{2+}$ adsorption may be related to the stability of the octahedral hydrated complexes $\mathrm{M}^{2+}\left(\mathrm{H}_{2} \mathrm{O}\right)_{6}$. The $\mathrm{Cu}^{2+}$ configuration is $\mathrm{d}^{9}$ in complex $\mathrm{Cu}\left(\mathrm{H}_{2} \mathrm{O}\right)_{6}$ and the Jahn-Teller effect occurs, which causes distortions in the bonding lengths, decreasing the binder-metal bonding energy. The decrease in bonding energy causes the loss of surrounding water molecules making the $\mathrm{Cu}^{2+}$ more available than other ions for bonding to the $\mathrm{SiImi}^{+} \mathrm{Cl}^{-}$material. The Jahn-Teller effect does not occur in $\mathrm{Ni}^{2+}$ and $\mathrm{Cd}^{2+}$ complexes because the configurations are $\mathrm{d}^{8}$ and $\mathrm{d}^{10}$, respectively. According to Cegłowski and Schroeder ${ }^{72}$ there was a strong interaction between $\mathrm{Cu}^{2+}$ ions and a binder containing pyridine and imidazole due to the high complexing property between ion and nitrogenous binder. The same authors also concluded that this does not occur with $\mathrm{Ni}^{2+}$ due to the low complexation property, which is a result of weak metalbinder interactions.

Considering the $\mathrm{SiImi}^{+} \mathrm{Cl}^{-}$chemical structure as shown in Figure 7, several adsorption mechanisms may be involved. According to the literature, four mechanisms for metal ions removal are possible using the adsorbent. The mechanisms are: complexation with nitrogen in the imidazole to the metal ions; ${ }^{73-75}$ ion exchange of residual $\mathrm{Si}-\mathrm{OH}$ groups with the metal ions; ${ }^{73-75}$ physisorption through van der Waals interactions of the alkyl chains in $\mathrm{SiImi}^{+} \mathrm{Cl}^{-}$with the metal ions ${ }^{73-75}$ and anionic complexation through the complexation of anionic metallic ion chlorides with positive nitrogenous groups of $\mathrm{SiImi}^{+} \mathrm{Cl}^{-} \cdot{ }^{41,43}$

The possible uptakes of metal ions via ion exchange were qualitatively confirmed according to the literature. ${ }^{73}$ The $\mathrm{pH}$ value for the metal ions before the adsorption decreased at the end of the adsorption process as shown in Figure 8. This implies that $\mathrm{Cu}^{2+}, \mathrm{Cd}^{2+}$ and $\mathrm{Ni}^{2+}$ were captured through ion exchange with $\mathrm{H}^{+}$. The release of this $\mathrm{H}^{+}$caused $\mathrm{pH}$ reduction.

To compare the adsorptive capacity of the material synthesized with other adsorbents, Table 2 shows the adsorptive capacities of some adsorbents for the $\mathrm{Cu}^{2+}, \mathrm{Cd}^{2+}$ and $\mathrm{Ni}^{2+}$ ions reported in the literature.

Among the adsorbents mentioned in the literature, ${ }^{33,40,41}$ $\mathrm{SiImi}^{+} \mathrm{Cl}^{-}$material was presented as an efficient adsorbent for ions. Comparing the adsorptive capacities of the 


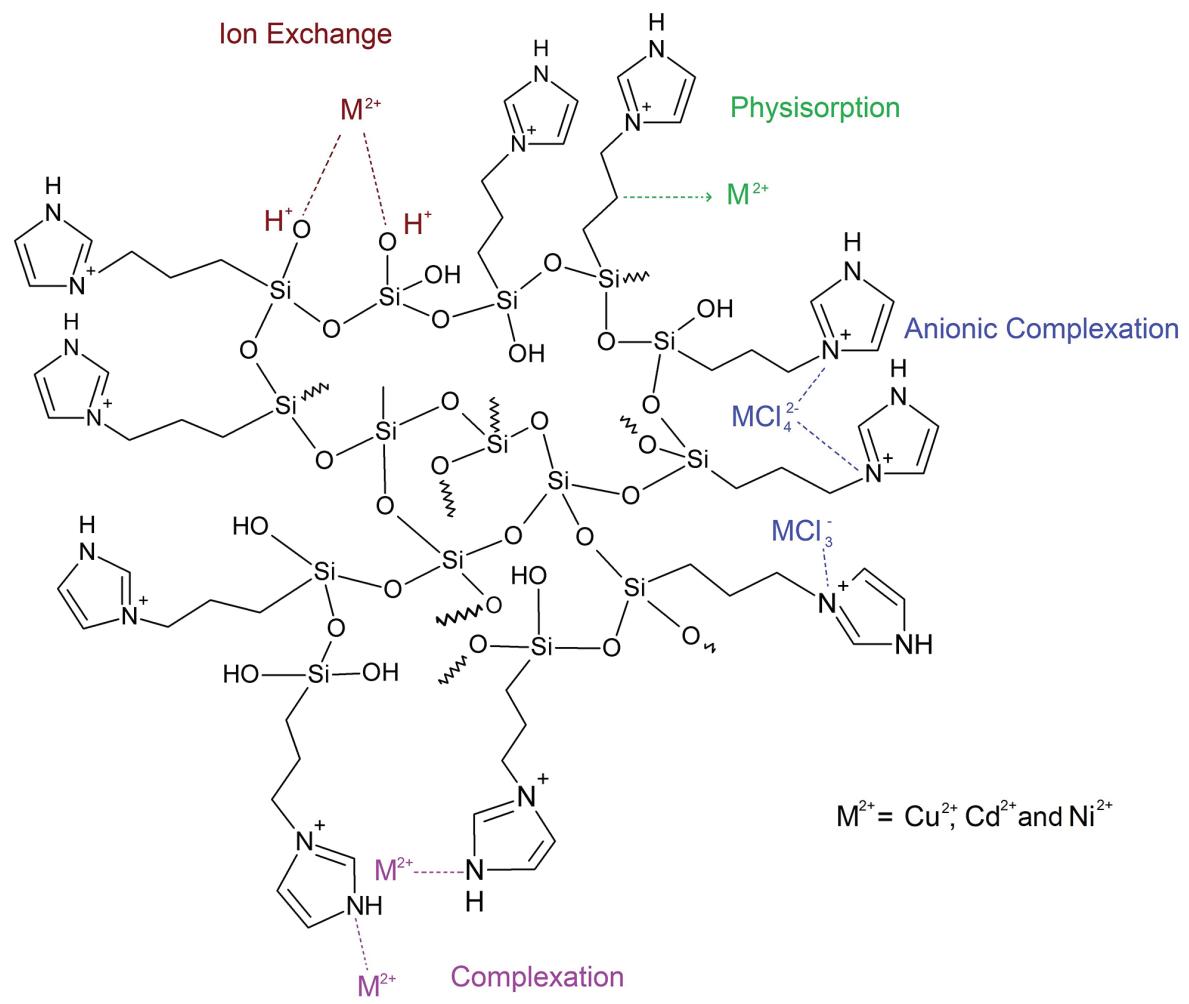

Figure 7. Possible mechanisms involved in $\mathrm{Cu}^{2+}, \mathrm{Cd}^{2+}$ and $\mathrm{Ni}^{2+}$ adsorption on $\mathrm{Silmi}^{+} \mathrm{Cl}^{-}$.

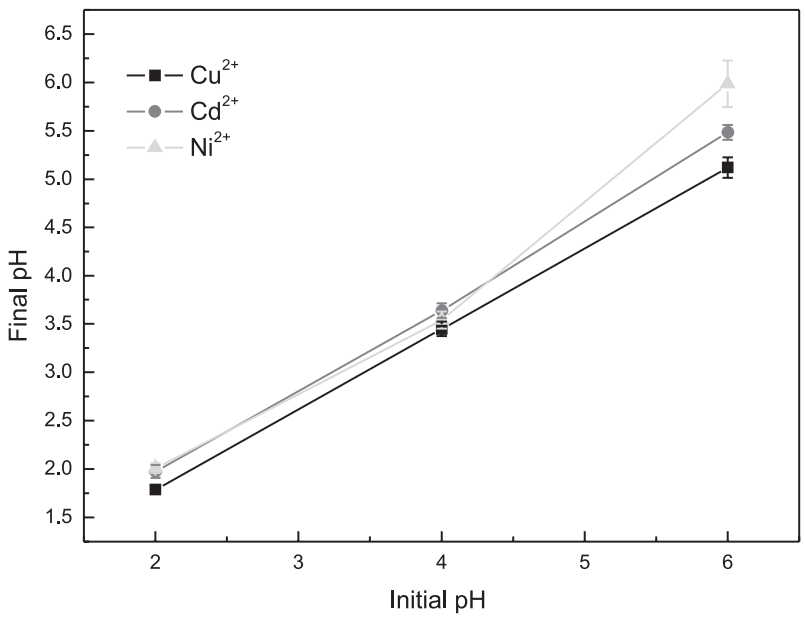

Figure 8. Relation between initial $\mathrm{pH}$ and final $\mathrm{pH}$ for $\mathrm{Cu}^{2+}, \mathrm{Cd}^{2+}$ and $\mathrm{Ni}^{2+}$ ions.

$\mathrm{SiImi}^{+} \mathrm{Cl}^{-}$material with the materials which are known to be excellent complexing agents of metal ions and are commercial mesoporous materials, excellent adsorption capacity of $\mathrm{Cu}^{2+}$ and $\mathrm{Cd}^{2+}$ ions and satisfactory adsorption of $\mathrm{Ni}^{2+}$ ions were observed.

\section{Conclusions}

The $\mathrm{SiImi}^{+} \mathrm{Cl}^{-}$silsesquioxane was organofunctionalized from the sol-gel method through the reaction between imidazole and silicon precursors
Table 2. Comparison of the adsorption capacity for $\mathrm{Cu}^{2+}, \mathrm{Cd}^{2+}$ and $\mathrm{Ni}^{2+}$ with silica-based adsorbents

\begin{tabular}{|c|c|c|c|c|}
\hline \multirow{2}{*}{ Adsorbent } & \multicolumn{3}{|c|}{ Adsorption capacity / $\left(\mathrm{mg} \mathrm{g}^{-1}\right)$} & \multirow{2}{*}{ Reference } \\
\hline & $\mathrm{Cu}^{2+}$ & $\mathrm{Cd}^{2+}$ & $\mathrm{Ni}^{2+}$ & \\
\hline KIT-6/EDTA ${ }^{\mathrm{a}}$ & 76.88 & 157.37 & 65.73 & 15 \\
\hline SBA-15/EDTA ${ }^{\mathrm{a}}$ & 85.78 & 120.27 & 66.90 & 15 \\
\hline $\mathrm{PBIm}^{\mathrm{b}}$ & 35.74 & - & - & 42 \\
\hline $\mathrm{Pim}^{\mathrm{b}}$ & 66.09 & - & - & 42 \\
\hline $\mathrm{NH}_{2}-\mathrm{MCM}-41 /$ Nylon6$^{c}$ & 35.8 & 27.6 & - & 66 \\
\hline T8-Pr-DPA ${ }^{\mathrm{d}}$ & 98.49 & 97.79 & 14.67 & 71 \\
\hline PMHS-g-PyPzAllyle & 94.04 & 106.79 & 46.36 & 72 \\
\hline PMHS-g-PyPz $(\mathrm{OEt})_{2} \mathrm{Allyl}^{\mathrm{e}}$ & 67.35 & 139.39 & 34.04 & 72 \\
\hline MCM-41/PEI ${ }^{\mathrm{f}}$ & - & 156.0 & 139.7 & 73 \\
\hline $\mathrm{NH}_{2}-\mathrm{MCM}-41^{\mathrm{g}}$ & - & 80.0 & 40.0 & 76 \\
\hline SBA-15/PAMAM ${ }^{\mathrm{h}}$ & 110.55 & 109.03 & - & 77 \\
\hline R-POSS/Nano-celulose ${ }^{\mathrm{i}}$ & 24.50 & - & 8.18 & 78 \\
\hline $\mathrm{CF}-\mathrm{S}-\mathrm{N}^{\mathrm{j}}$ & 197.44 & 187.43 & - & 79 \\
\hline SiImi $^{+} \mathrm{Cl}^{-\mathrm{k}}$ & 177.91 & 155.12 & 59.64 & this work \\
\hline
\end{tabular}

${ }^{a}$ Ethylenediamine tetraacetic acid (EDTA) modified with mesoporous silica; ${ }^{\text {p}}$ poly(dimethylsiloxane) networks functionalized with imidazole or benzimidazole; ' porous amine-modified nanocomposite; ${ }^{\mathrm{d}}$ nanostructured organosilicate octakis[3-(2,2'-dipyridylamine)propyl]octasilsesquioxane; ${ }^{\mathrm{e}}$ silica polymers obtained by grafting pyridine-pyrazole ligands onto polymethylhydrosiloxane; ${ }^{\mathrm{f}}$ nano-spherical amine-rich polyethylenimine (PEI) grafted on mesoporous; ' ${ }^{\text {m}}$ mesoporous materials including amino groups; hunctionalized mesoporous silica with polyamidoamine groups; 'nano-cellulose hybrids containing reactive polyhedral oligomeric silsesquioxanes; ${ }^{j}$ porous magnetic composite functionalized by 3 -aminopropyltriethoxysilane; ${ }^{k} \mathrm{SiImi}^{+} \mathrm{Cl}^{-}: 3-n$-propylimidazolium silsesquioxane chloride. 
(3-chloropropyltrimetoxysilane and tetraethylorthosilicate). This synthesis was successfully obtained, as it could be observed mainly by the analysis such as FTIR and NMR. The adsorption of $\mathrm{Cu}^{2+}, \mathrm{Cd}^{2+}$ and $\mathrm{Ni}^{2+}$ ions was performed with high adsorption isotherms. In general, the Sips isotherms had higher regression coefficients than Langmuir and Freundlich. This suggests the heterogeneous surface condition coexist with monolayer sorption under the experimental conditions. According to the results, the adsorption of metal ions occurs in the order $\mathrm{Cu}^{2+}>\mathrm{Cd}^{2+}>\mathrm{Ni}^{2+}$, mainly due to the higher affinity of the material for $\mathrm{Cu}^{2+}$ ions and lower for $\mathrm{Ni}^{2+}$ ions. When comparing the adsorbents reported in the literature, regarding the adsorption of metal ions, some silica-based materials and chelating group such as ethylenediamine tetraacetic acid (EDTA), the synthesized material has been seen to adsorb a relatively higher amount for metal ions in general.

\section{Supplementary Information}

Supplementary information is available free of charge at http://jbcs.sbq.org.br as PDF file and presents the species diagram of ions $\mathrm{Cu}^{2+}, \mathrm{Ni}^{2+}$ and $\mathrm{Cd}^{2+}$.

\section{Acknowledgments}

ACR and VJVH are indebted to CAPES for the fellowship. RAE and STF are indebted to CAPES, Fundação Araucária and CNPq for the financial support. The authors are also indebted to CLABMU/UEPG for the equipment and analyses.

\section{References}

1. Repo, E.; Warchoł, J. K.; Bhatnagar, A.; Sillanpää, M.; J. Colloid Interface Sci. 2011, 358, 261.

2. Grigoropoulou, G.; Stathi, P.; Karakassides, M. A.; Louloudi, M.; Deligiannakis, Y.; Colloids Surf., A 2008, 320, 25.

3. Farzin, L.; Shamsipur, M.; Sheibani, S.; Talanta 2017, 174, 619.

4. Singh, N.; Gupta, V. K.; Kumar, A.; Sharma, B.; Front. Chem. 2017, 5, DOI: 10.3389/fchem.2017.00070.

5. Romaniuk, A.; Sikora, V.; Lyndin, M.; Smiyanov, V.; Sikora, V.; Lyndina, Y.; Piddubnyi, A.; Gyryavenko, N.; Korobchanska, A.; Interv. Med. Appl. Sci. 2017, 9, 105.

6. Larsson, S. C.; Wolk, A.; Int. J. Epidemiol. 2015, 45, 782.

7. Rzymski, P.; Tomczyk, K.; Rzymski, P.; Poniedziałek, B.; Opala, T.; Wilczak, M.; Ann. Agric. Environ. Med. 2015, 22, 259.

8. Hu, H.; Li, X.; Huang, P.; Zhang, Q.; Yuan, W.; J. Environ. Manage. 2017, 203, 1.

9. Li, Y.; Wang, J.; Yue, Z.; Tao, W.; Yang, H.; Zhou, Y.; Chen, T.; J. Biosci. Bioeng. 2017, 124, 71.
10. Carro, L.; Barriada, J. L.; Herrero, R.; Sastre de Vicente, M. E.; Chem. Eng. J. 2015, 264, 181.

11. Zamri, M. F. M. A.; Kamaruddin, M. A.; Yusoff, M. S.; Aziz, H. A.; Foo, K. Y.; Appl. Water Sci. 2017, 7, 581.

12. Zhu, X.; Li, W.; Zhan, L.; Huang, M.; Zhang, Q.; Achal, V.; Environ. Pollut. 2016, 219, 149.

13. Ozcelik, G.; Imamoglu, M.; Yildiz, S. Z.; Kara, D.; Water, Air, Soil Pollut. 2012, 223, 5391.

14. Chethan, P. D.; Vishalakshi, B.; Carbohydr. Polym. 2013, 97 , 530.

15. Ezzeddine, Z.; Batonneau-Gener, I.; Pouilloux, Y.; Hamad, H.; Saad, Z.; Kazpard, V.; Microporous Mesoporous Mater. 2015, 212,125

16. Yin, X. C.; Liu, X.; Fan, J. C.; Wu, J. J.; Men, J. L.; Zheng, G. S.; J. Appl. Polym. Sci. 2017, 134, 44466.

17. Culita, D. C.; Simonescu, C. M.; Patescu, R. E.; Preda, S.; Stanica, N.; Munteanu, C.; Oprea, O.; J. Inorg. Organomet. Polym. Mater. 2017, 27, 490.

18. Zhao, D.; Yu, Y.; Chen, J. P.; Water Res. 2016, 101, 564.

19. Li, L.; Zhang, J.; Li, Y.; Yang, C.; J. Membr. Sci. 2017, 544, 333.

20. Nemati, M.; Hosseini, S. M.; Shabanian, M.; J. Hazard. Mater. 2017, 337, 90.

21. Nagarajah, R.; Wong, K. T.; Lee, G.; Chu, K. H.; Yoon, Y.; Kim, N. C.; Jang, M.; Sep. Purif. Technol. 2017, 174, 290.

22. Sayar, O.; Amini, M. M.; Moghadamzadeh, H.; Sadeghi, O.; Khan, S. J.; Microchim. Acta 2013, 180, 227.

23. Ren, C.; Ding, X.; Fu, H.; Li, W.; Wu, H.; Yang, H.; RSC Adv. 2017, 7, 6911.

24. Chen,H.;Luo,J.;Wang,X.;Liang, X.;Zhao,Y.;Yang, C.; Baikenov, M. I.; Su, X.; Microporous Mesoporous Mater. 2018, 255, 69.

25. Ismail, A. A.; Mohamed, R. M.; Ibrahim, I. A.; Kini, G.; Koopman, B.; Colloids Surf., A 2010, 366, 80.

26. Iler, R. K.; The Chemistry of Silica-Solubility, Polymerization, Colloid and Surface Properties, and Biochemistry; John Wiley and Sons: New York, 1979.

27. Magosso, H. A.; Fattori, N.; Kholin, Y. V.; Gushikem, Y.; J. Braz. Chem. Soc. 2009, 20, 744.

28. Fattori, N.; Maroneze, C. M.; Magosso, H. A.; Kholin, Y. V.; Gushikem, Y.; J. Colloid Interface Sci. 2012, 384, 137.

29. do Carmo, D. R.; Bicalho, U. O.; Silveira, T. F. A.; Filho, N. L. D.; Paim, L. L.; J. Chem. 2013, 2013, 509341.

30. Parambadath, S.; Mathew, A.; Barnabas, M. J.; Kim, S. Y.; Ha, C. S.; J. Sol-Gel Sci. Technol. 2016, 79, 426.

31. Da'na, E.; Microporous Mesoporous Mater. 2017, 247, 145.

32. Dias Filho, N. L.; Costa, R. M.; Marangoni, F.; Pereira, D. S.; J. Colloid Interface Sci. 2007, 316, 250.

33. Tzvetkova, P.; Vassileva, P.; Nickolov, R.; J. Porous Mater. 2010, $17,459$.

34. Zhao, Y.; Zhai, S. R.; Zhai, B.; An, Q. D.; J. Sol-Gel Sci. Technol. 2012, 62, 177. 
35. Brinker, J. C.; Scherer, G. W.; Sol-Gel Science-The Physics and Chemistry of Sol-Gel Processing; Academic Press: New York, 1990.

36. Wen, J.; Wilkes, G. L.; Chem. Mater. 1996, 8, 1667.

37. Ciriminna, R.; Fidalgo, A.; Pandarus, V.; Béland, F.; Ilharco, L. M.; Pagliaro, M.; Chem. Rev. 2013, 6592.

38. Lim, M.; Stein, A.; Chem. Mater. 1999, 11, 3285.

39. Stein, A.; Melde, B. J.; Schroden, R. C.; Adv. Mater. 2000, 12, 1403.

40. Fujiwara, S. T.; Gushikem, Y.; Alfaya, R. V. S.; Colloids Surf., A 2001, 178, 135 .

41. Magosso, H. A.; Panteleimonov, A. V.; Kholin, Y. V.; Gushikem, Y.; J. Colloid Interface Sci. 2006, 303, 18.

42. Pissetti, F. L.; de Araújo, P. L.; Silva, F. A. B.; Poirier, G. Y.; J. Braz. Chem. Soc. 2015, 26, 266.

43. Panteleimonov, A. V.; Onizhuk, M. O.; Khristenko, I. V.; Chuiko, I. I.; Tkachenko, O. S.; Gushikem, Y.; Kholin, Y. V.; J. Braz. Chem. Soc. 2015, 26, 1160.

44. Lee, M.; Goldburg, W. I.; Phys. Rev. 1965, 140, 1262.

45. Gushikem, Y.; Benvenutti, E. V.; Kholin, Y. V.; Pure Appl. Chem. 2008, 80, 1593.

46. Albert, K.; Bayer, E.; J. Chromatogr. A 1991, 544, 345.

47. Vieira, E. G.; Soares, I. V.; da Silva, N. C.; Perujo, S. D.; do Carmo, D. R.; Dias Filho, N. L.; New J. Chem. 2013, 37, 1933.

48. Maroneze, C. M.; Magosso, H. A.; Panteleimonov, A. V.; Kholin, Y. V.; Gushikem, Y.; J. Colloid Interface Sci. 2011, 356, 248.

49. da Silva, P. S.; Gasparini, B. C.; Magosso, H. A.; Spinelli, A.; J. Hazard. Mater. 2014, 273, 70.

50. Auler, L. M. L. A.; Silva, C. R.; Collins, K. E.; Collins, C. H.; J. Chromatogr. A 2005, 1073, 147.

51. Kawano, Y.; Denofre, S.; Gushikem, Y.; Vib. Spectrosc. 1994, 7, 293.

52. Innocenzi, P.; J. Non-Cryst. Solids 2017, 316, 309.

53. Creff, G.; Arrachart, G.; Hermet, P.; Wadepohl, H.; Almairac, R.; Maurin, D.; Sauvajol, J. L.; Carcel, C.; Moreau, J. J. E.; Dieudonné, P.; Man, M. W. C.; Bantignies, J. L.; Phys. Chem. Chem. Phys. 2012, 14, 5672.

54. Donato, R. K.; Migliorini, M. V.; Benvegnu, M. A.; Stracke, M. P.; Gelesky, M. A.; Pavan, F. A.; Schrekker, C. M. L.; Benvenutti, E. V.; Dupont, J.; Schrekker, H. S.; J. Sol-Gel Sci. Technol. 2009, $49,71$.

55. Yu, F.; Yao, K.; Shi, L.; Wan, W.; Zhong, Q.; Fu, Y.; You, X.; Chem. Mater. 2007, 19, 3412.

56. Arenas, L. T.; Aguirre, T. A. S.; Langaro, A.; Gushikem, Y.; Benvenutti, E. V.; Costa, T. M. H.; Polymer (Guildf). 2003, 44, 5521.

57. da Trindade, C. M.; Stoll, G. C.; Pereira, A. S.; Costa, T. M. H.; Benvenutti, E. V.; J. Braz. Chem. Soc. 2009, 20, 737.

58. Nowacka, M.; Kowalewska, A.; Makowski, T.; Polymer 2016, 87,81 .
59. Lerouge, F.; Cerveau, G.; Corriu, R. J. P.; J. Mater. Chem. 2006, 16, 90.

60. Pavlenko, V. I.; Cherkashina, N. I.; Demkina, L. N.; Mater. Sci. Eng. 2018, 327, 1.

61. Yin, P.; Xu, Q.; Qu, R.; Zhao, G.; Sun, Y.; J. Hazard. Mater. 2010, 173, 710 .

62. Sun, J.; Chen, Z.; Ge, M.; Xu, L.; Zhai, M.; J. Hazard. Mater. 2013, 244-245, 94.

63. Ndayambaje, G.; Laatikainen, K.; Laatikainen, M.; Beukes, E.; Fatoba, O.; van der Walt, N.; Petrik, L.; Sainio, T.; Chem. Eng. J. 2016, 284, 1106

64. Alfaya, R. V. S.; Fujiwara, S. T.; Gushikem, Y.; Kholin, Y. V.; J. Colloid Interface Sci. 2004, 269, 32.

65. Shariful, M. I.; Sepehr, T.; Mehrali, M.; Ang, B. C.; Amalina, M. A.; J. Appl. Polym. Sci. 2018, 135, 1.

66. Mohammadnezhad, G.; Soltani, R.; Abad, S.; Dinari, M.; J. Appl. Polym. Sci. 2017, 134, 45383.

67. Jiang, Y.; Gao, Q.; Yu, H.; Chen, Y.; Deng, F.; Microporous Mesoporous Mater. 2007, 103, 316.

68. Ayawei, N.; Ebelegi, A. N.; Wankasi, D.; J. Chem. 2017, 2017, 3039817.

69. Wang, S.; Kwak, J.; Islam, S.; Naeth, M. A.; El-din, M. G.; Chang, S. X.; Sci. Total Environ. 2020, 712, 136538.

70. Mahdi, Z.; Hanandeh, A. El; Yu, Q. J.; J. Environ. Chem. Eng. 2019, 7, 103379 .

71. Vieira, E. G.; Soares, I. V.; Filho, N. L. D.; da Silva, N. C.; Perujo, S. D.; Bastos, A. C.; Garcia, E. F.; Ferreira, T. T.; Fraceto, L. F.; Rosa, A. H.; J. Hazard. Mater. 2012, 237-238, 215.

72. Cegłowski, M.; Schroeder, G.; Chem. Eng. J. 2015, 259, 885.

73. Thakur, A. K.; Nisola, G. M.; Limjuco, L. A.; Parohinog, K. J.; Torrejos, R. E. C.; Shahi, V. K.; Chung, W. J.; J. Ind. Eng. Chem. 2017, 49, 133.

74. Kudryavtsev, G. V.; Miltchenko, D. V.; Yagov, V. V.; Lopatkin, A. A.; J. Colloid Interface Sci. 1990, 140, 114.

75. Ghorbani, M.; Nowee, S. M.; Ramezanian, N.; Raji, F.; Hydrometallurgy 2016, 161, 117.

76. Lam, K. F.; Yeung, K. L.; McKay, G.; Environ. Sci. Technol. 2007, 41, 3329.

77. Shahbazi, A.; Younesi, H.; Badiei, A.; Can. J. Chem. Eng. 2013, 91, 739 .

78. Xie, K.; Jing, L.; Zhao, W.; Zhang, Y.; J. Appl. Polym. Sci. 2011, 122,2864

79. Ren, C.; Ding, X.; Li, W.; Wu, H.; Yang, H.; J. Chem. Eng. Data 2017, 62, 1865.

Submitted: November 1, 2019 Published online: June 1, 2020 